\title{
The stiffening of the cell walls observed during physiological softening of pears
}

\author{
Artur Zdunek $^{1} \cdot$ Arkadiusz Kozioł $^{1} \cdot$ Justyna Cybulska $^{1} \cdot$ Małgorzata Lekka $^{2}$. \\ Piotr M. Pieczywek ${ }^{1}$
}

Received: 31 July 2015/Accepted: 13 October 2015/Published online: 26 October 2015

(c) The Author(s) 2015. This article is published with open access at Springerlink.com

\begin{abstract}
Main conclusion The Young's modulus of the primary cell walls of pears decreases linearly during the preharvest on-tree maturation and increases during postharvest storage, and does not correlate with firmness of fruit.
\end{abstract}

The determination of mechanical properties of cell walls is indispensable for understanding the mechanism of physiological softening and deterioration of quality of fruits during postharvest storage. The Young's modulus of the primary cell walls from pear fruit (Pyrus communis L., cultivars 'Conference' and 'Xenia') during pre-harvest maturation and postharvest storage in an ambient

Electronic supplementary material The online version of this article (doi:10.1007/s00425-015-2423-0) contains supplementary material, which is available to authorized users.

Artur Zdunek

a.zdunek@ipan.lublin.pl

Arkadiusz Kozioł

a.koziol@ipan.lublin.pl

Justyna Cybulska

j.cybulska@ipan.lublin.pl

Małgorzata Lekka

malgorzata.lekka@gmail.com

Piotr M. Pieczywek

p.pieczywek@ipan.lublin.pl

1 Institute of Agrophysics, Polish Academy of Sciences, Doświadczalna 4, 20-290 Lublin, Poland

2 The Henryk Niewodniczański Institute of Nuclear Physics, Polish Academy of Sciences, Radzikowskiego 152, 31-342 Kraków, Poland atmosphere at $2{ }^{\circ} \mathrm{C}$ followed by shelf life was studied using atomic force microscopy (AFM). The results were related to the firmness of fruits, galacturonic acid content in water, chelator, sodium carbonate and insoluble pectin fractions, polygalacturonase and pectin methylesterase activities. The Young's modulus of the primary cell walls decreased linearly during the last month of pre-harvest maturation from $3.2 \pm 1.8$ to $1.1 \pm 0.7 \mathrm{MPa}$ for 'Conference' and from $1.9 \pm 1.2$ to $0.2 \pm 0.1 \mathrm{MPa}$ for 'Xenia' which correlated with linear firmness decrease. During postharvest storage the cell wall Young's modulus increased while firmness continued to decrease. Correlation analysis for the entire period of the experiment showed a lack of straightforward relation between the Young's modulus of primary cell walls and fruit firmness. The Young's modulus of cell walls correlated negatively either with galacturonic acid content in sodium carbonate soluble pectin ('Conference') or with insoluble pectin fractions ('Xenia') and positively with polygalacturonase activity. It was therefore evidenced that covalently linked pectins play the key role for the stiffness of fruit cell walls. Based on the obtained results, the model explaining the fruit transition from firm and crispy to soft and mealy was proposed.

Keywords Atomic force microscopy (AFM) - Cell wall · Firmness · Pear · Stiffness · Young's modulus
Abbreviations
AFM Atomic force microscopy
CWM Cell wall material
DASP Sodium carbonate soluble pectins
GalA Galacturonic acid
PG Polygalacturonase
PME Pectin methylesterase 


\section{Introduction}

Cell walls determine macroscopic mechanical properties of fruit (Jarvis 2011; Cybulska et al. 2013; Gwanpua et al. 2014), as well as water transport and shrinkage (Fanta et al. 2014). Thus, the cell wall stiffness is a key parameter which must be considered to understand the mechanism of fruit softening. Stiffness (quantitatively described by the Young's or elasticity modulus) is one of the most important parameters in microstructure-based models used for the prediction of macroscopic properties of plants (Fanta et al. 2014; Pieczywek and Zdunek 2014). Material properties of cell walls in plants change during growth and development due to biosynthesis and degradation of its constituents (Albersheim et al. 2011). It is also true for climacteric fruit where cell walls undergo substantial biochemical changes during on tree and postharvest maturation (Brummell and Harpster 2001). Although it is generally believed that during fruit ripening, the cell walls loosen and become weaker, neither the structural bases of these changes (Vicente et al. 2007) nor experimental evidences have been provided, so far. This is largely due to problems with the evaluation of cell wall structure and mechanical properties in conditions close to natural ones.

Measurements of cell wall elastic properties are difficult due to their small physical dimensions on the micrometer scale. So far, only a few methods have been developed to estimate mechanical properties of cell wall that may be applied to fruit. However, these developments focused on the estimation of cell wall properties from intact cells. In the micro-compression test, an individual living cell was compressed between two plates and a resulting force-displacement curve together with a computational model allowed for elucidation of properties of the cell wall (Mashmoushy et al. 1998; Shiu et al. 1999; Thomas et al. 2000; Blewett et al. 2000). A micro-penetration test was also applied for cell wall studies on intact tissue. Penetration of tissue was carried out using a parallel-sided probe with a diameter of about $15 \%$ of a cell size (Hiller et al. 1996) and the deformation of a cell wall was simulated by a membrane analytical model which allowed to estimate cell wall stiffness (Davies et al. 1998). Micro-indentation is a similar technique to micro-penetration however uses smaller deformations (Routier-Kierzkowska and Smith 2013). It is performed by a flat or rounded indenter, a few micrometers in diameter $(1-5 \mu \mathrm{m})$. Typically, the indentation depth is comparable to or larger than the cell wall thickness and the force is in a range of $1-100 \mu \mathrm{N}$. A device that allows the automation of micro-indentation measurements is the cellular force microscope (CFM) (RoutierKierzkowska et al. 2012).

An atomic force microscope (AFM) has been applied for nano-indentation of biological materials (Radmacher et al.
1994, 1995; Kuznetsova et al. 2007; Lekka and Laidler 2009; Lekka 2012; Lekka et al. 2012; Kurland et al. 2012). The technique combines imaging of surface topography with a nanometer resolution and sensing of the nano-mechanical properties of the sample. The Young's modulus for each sample has been determined by fitting a mathematical model describing the contact mechanics between the AFM tip and sample. The Hertz-Sneddon model is the most commonly used one, under the assumption that a sample is a linearly elastic and isotropic solid with thickness infinitely extending to a half space (Sneddon 1965). The AFM has been recently applied to measure mechanical properties of plant cells: suspended grapevine cells grown in liquid medium (Lesniewska et al. 2004), the primary cell wall of shoot apical meristems (Milani et al. 2011, Peaucelle et al. 2011), rosette leaves (Hayot et al. 2012) and epidermal cells of living roots of Arabidopsis thaliana (Fernandes et al. 2012), and suspended cells extracted from tomato pericarp (Zdunek and Kurenda 2013). However, the method has not yet been applied to evaluate the changes of cell wall stiffness during fruit maturation.

The evaluation of the Young's modulus of the wall in intact plant cells, regardless of the method used, requires the assumptions about turgor pressure and cell wall thickness that are usually difficult to estimate. This difficulty and the problem of small dimensions of natural cell walls has been partially solved by performing mechanical tests on model membranes composed of bacterial cellulose, pectins and xyloglucan (Cybulska et al. 2010, 2011). The material composition of these membranes is similar to the natural cell walls and may be considered as a representative system to simulate various effects. However, the artificial materials are not able to mimic complex biochemical processes occurring in fruit cell walls during maturation.

In our work, the procedure for stiffness measurements of cell walls extracted from fruit with the use of the AFM was elaborated. To avoid problems with the turgor and cell wall thickness, measurements were performed on cell wall fragments prepared as alcohol insoluble residues after tissue crushing. The cell walls were studied in deionized water, thus in a hydrated state that mimics the conditions close to natural ones. The goal of our studies was to evaluate the Young's modulus of the cell walls as a function of maturation time, including pre-harvest development (i.e., fruit on trees) and postharvest storage of two pear (Pyrus communis L.) cultivars 'Xenia' and 'Conference'. Such an approach enabled us to investigate the relation between cell wall stiffness and macroscopic firmness of fruit. Changes in mechanical properties of cell walls were interpreted based on their biochemical characteristics, i.e., the presence of galacturonic acid in pectin fractions, polygalacturonase and pectin methylesterase activities. The 
obtained results provided an important contribution into a structure-based model of fruit softening.

\section{Materials and methods}

\section{Fruits}

Pear (Pyrus communis L.) fruits of two cultivars 'Conference' and 'Xenia' from the same orchard were used in our studies. Pears were picked at five pre-harvest stages within 27 and 34 days before harvest for 'Conference' and 'Xenia', respectively. In this period, pears were already fully expanded. Pears harvested at the optimum time were stored in a cold room at $2{ }^{\circ} \mathrm{C}$ and $\mathrm{RH} \sim 80-90 \%$ in ambient atmosphere for 120-145 days for 'Conference' and 'Xenia', respectively. During this period, the material was studied at five stages for 'Conference' and four stages for 'Xenia' with an interval of $\sim 30$ days. Each stage was followed by 3-7 days of shelf life at $20{ }^{\circ} \mathrm{C}$ and $\mathrm{RH}$ $\sim 40-50 \%$ to stimulate softening. In total, the experiment consisted of 15 stages for each cultivar. Each batch of pears consisted of at least ten fruits of similar size without visible damages. These pears were used first for firmness determination and then smashed for collection of cell wall material and for other biochemical analyses.

\section{Firmness}

Firmness of individual pears without skin was measured using a universal testing machine (Lloyd LRX, Lloyd Instruments Ltd., Hampshire, UK) in the puncture test with a probe of $11.1 \mathrm{~mm}$. A crosshead speed was set to $20 \mathrm{~mm} /$ min and maximum penetration depth was $8 \mathrm{~mm}$. Firmness was defined as the maximum force value observed in a force-penetration curve.

\section{Cell wall material (CWM)}

Cell wall material (CWM) was isolated from parenchyma tissue as alcohol insoluble residue (AIR), (Renard 2005). $20 \mathrm{~g}$ of fruit pulp was boiled with $70 \mathrm{ml}$ of $70 \%$ ethanol for $20 \mathrm{~min}$. The sample was chilled, filtered using a nylon filter and mixed with $30 \mathrm{ml}$ of $70 \%$ ethanol. After filtration and a negative result from the phenol-sulfuric acid assay for the presence of sugars (Dubois et al. 1956), the sample was washed twice with $10 \mathrm{ml}$ of $96 \%$ ethanol and $50 \mathrm{ml}$ acetone and dried at $40{ }^{\circ} \mathrm{C}$.

\section{Pectin fractions}

Pectins were isolated during sequential extraction according to the method proposed by Redgwell et al. (1988) with some modifications. AIR was stirred in deionized water for $6 \mathrm{~h}$ at $20^{\circ} \mathrm{C}$ and then centrifuged. The supernatant was collected as the WSP fraction, whereas the residue was mixed with $0.1 \mathrm{M}$ cyclohexane-trans-1,2-diamine tetraacetate (CDTA) (pH 6.5) and stirred at $25^{\circ} \mathrm{C}$ for $6 \mathrm{~h}$, filtered and again stirred with CDTA for $2 \mathrm{~h}$. The supernatant was separated as the CSP fraction and the residue was diluted in $0.05 \mathrm{M}$ sodium carbonate $\left(\mathrm{Na}_{2} \mathrm{CO}_{3}\right)$ and $20 \mathrm{mM}$ sodium borohydride $\left(\mathrm{NaBH}_{4}\right)$ was added. This solution was then stirred for approximately $20 \mathrm{~h}$ at $1{ }^{\circ} \mathrm{C}$, filtered and again stirred in the same solvent for $2 \mathrm{~h}$ at $20^{\circ} \mathrm{C}$. The DASP fraction was collected after centrifugation as a supernatant and a residue was collected to determine the GalA content in the insoluble pectin fraction.

\section{Galacturonic acid (GalA) content}

Galacturonic acid (GalA) in pectic fraction contents was determined using the $\mathrm{San}^{++}$Continuous Flow Analyzer (Skalar, Breda, The Netherlands) according to the colorimetric method by Blumenkrantz and Asboe-Hansen (1973). The sample was totally decomposed in $96 \%$ sulfuric acid $\left(\mathrm{H}_{2} \mathrm{SO}_{4}\right)$ with di-sodium tetra borate $\mathrm{Na}_{2} \mathrm{~B}_{4}$ $\mathrm{O}_{7} 10 \mathrm{H}_{2} \mathrm{O}$. Then the products were transformed into furfuric derivatives. The derivatives reacted with the 3-phenyl phenol to form a colored dye, which was measured at $530 \mathrm{~nm}$. Galacturonic acid solutions (10-100 $\mu \mathrm{g} /$ $\mathrm{ml}$ ) were used as standards. GalA content in pectin fractions was expressed in microgram per milligram of AIR.

\section{Polygalacturonase (PG) and pectin methylesterase (PME) enzymatic activity}

Enzymatic activity of pectinases was determined according to the method described by Wei et al. (2010) with some modifications. Briefly, enzymes of a cell wall were extracted from frozen fruit pulp. Powdered $3 \mathrm{~g}$ flesh was stirred into $6 \mathrm{ml}$ of cold $12 \%$ polyethyleneglycol containing $0.2 \%$ sodium bisulite and centrifuged for $10 \mathrm{~min}$ at $6000 \mathrm{~g}$. The pellet was washed with $0.2 \%$ sodium bisulfite at $4{ }^{\circ} \mathrm{C}$. Next the pellet was extracted with $6 \mathrm{ml}$ of cold extraction buffer containing $1 \mathrm{M}$ sodium acetate $(\mathrm{pH} 5.2)$, $1 \mathrm{M} \mathrm{NaCl}, 2 \%$ (v/v)-mercaptoethanol, and $5 \%(\mathrm{w} / \mathrm{v})$ polyvinylpyrrolidone (PVP), at $4{ }^{\circ} \mathrm{C}$ for $1 \mathrm{~h}$. The homogenate was centrifuged for $10 \mathrm{~min}$ at $6000 \mathrm{~g}$, and the supernatant was used to assay for enzyme activity.

Polygalacturonase (PG) activity was determined in the following way: enzyme extract $(0.2 \mathrm{ml})$ was mixed with $0.8 \mathrm{ml}$ of $0.5 \%$ polygalacturonic acid in $50 \mathrm{mM}$ sodium acetate buffer ( $\mathrm{pH} 5.2$ ), and incubated at $37{ }^{\circ} \mathrm{C}$ for $2 \mathrm{~h}$. Next, $2 \mathrm{ml}$ of borate buffer $(0.1 \mathrm{M}, \mathrm{pH} 9.0)$ and $0.3 \mathrm{ml}$ of cyanoacetamide were added to the reaction mixture. After inactivation of the enzymes by boiling for $10 \mathrm{~min}$ and then 
cooling, absorbance was read at $320 \mathrm{~nm}$. GalA was used as standard. One unit of activity was defined as $1 \mu \mathrm{g}$ of GalA released from gram fresh weight $(\mathrm{FW})$ per minute.

To determine the activity of pectin methylesterase (PME), $1 \mathrm{ml}$ of crude extract was mixed with $4 \mathrm{ml}$ of $1 \%$ (w/v) citrus pectin and titrated with $0.01 \mathrm{M} \mathrm{NaOH}$ to maintain $\mathrm{pH} 7.4$ while incubating at $37^{\circ} \mathrm{C}$ for $1 \mathrm{~h}$. One unit of activity was calculated as $1 \mu \mathrm{mol} \mathrm{NaOH}$ consumed by gram FW per minute.

\section{Cell wall stiffness}

CWM suspension $(1 \mathrm{mg} / \mathrm{ml})$ was dropped on a microscope glass slide and then air-dried. Ten minutes before tests, ultrapure water (Milipore) was added to swell samples (Fig. 1a).

Atomic force microscope (AFM) Bioscope Catalyst II equipped with Nanoscope V controller (Bruker, Billerica, MA, USA) was working in an indentation-type mode (Loparic et al. 2010). For indentation, a silicon nitride cantilever SNL10 (Bruker) with a nominal spring constant $k_{n}=0.35 \mathrm{~N} / \mathrm{m}$ and a resonance frequency $\omega_{n}=65 \mathrm{kHz}$ was chosen. A mean opening angle of the tip $\alpha=20.8^{\circ} \pm 5.2^{\circ}$ was calculated from the front, back and side angles. The measured resonance frequency of thermally excited cantilevers in air was $\omega=57.8 \pm 1.0 \mathrm{kHz}$. With the assumption that the actual mass of cantilever is equal to that of a nominal one, the spring constant was calculated from the proportion $k / k_{n}=\omega^{2} / \omega_{n}^{2}$. The obtained value of the cantilever spring constant was $k=0.28 \pm 0.01 \mathrm{~N} / \mathrm{m}$. Deflection sensitivity $(\mathrm{nm} / \mathrm{V})$ was determined from measurements carried out on glass substrate in aqueous conditions (Fig. 1b). At least five repetitions were made for both calibration steps. The force $F$ (in $\mathrm{nN}$ ) was calculated using Hooke's law $F=k x$, where $x$ is the cantilever deflection (in $\mathrm{nm}$ ).

For the each stage of the experiment, ten randomly chosen fragments of CWM were tested. For the each CWM, a scan of $10 \mu \mathrm{m} \times 10 \mu \mathrm{m}$ was recorded and then 64 force curves with an approach rate of $1 \mu \mathrm{m} / \mathrm{s}$ were collected in a regular grid of $8 \times 8$ points: the distance between points was $1.43 \mu \mathrm{m}$ (Fig. 1a). The Young's modulus $E$ was calculated for each individual force curve (a)

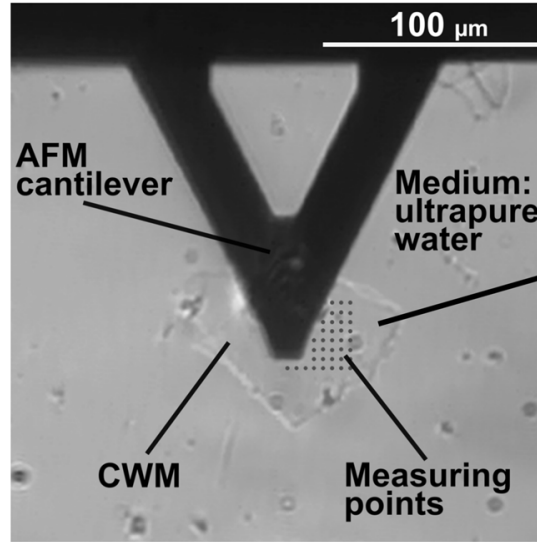

(b)

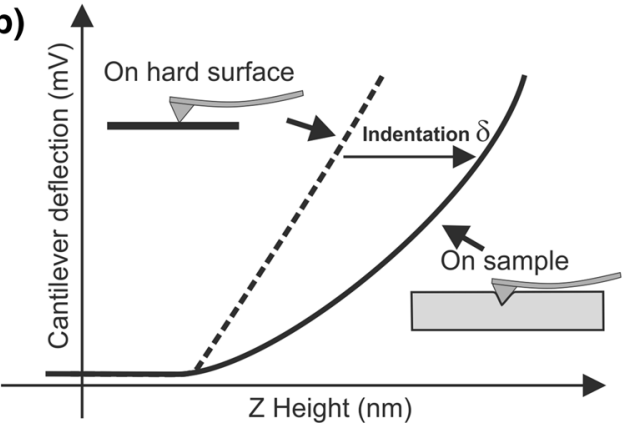

Fig. 1 The idea of the Young's modulus $E$ estimation for cell walls. a Top view image showing the AFM cantilever and a fragment of the cell wall material (CWM) in water. Dots denote a grid of points set for the force curve collection. b Schematic presentation of how the indentation is determined on a soft sample. Dashed line is sensitivity calibration curve recorded on a glass slide (an infinite hard surface). (c)

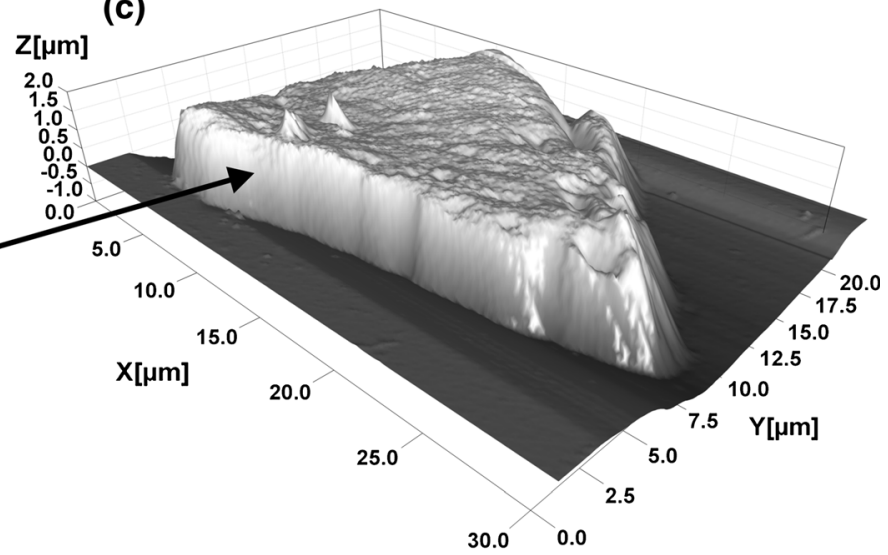

(d)

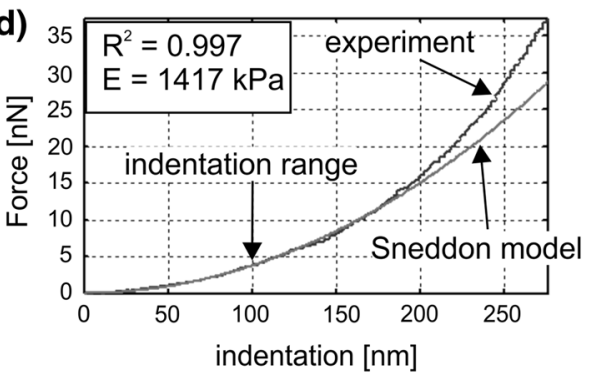

c Example of 3D topography of CWM used in experiment which showed that thickness of cell walls in pears is about $1 \mu \mathrm{m}$. d Screenshot from the proprietary code used to fit the Hertz-Sneddon model to the experimental data within the indentation depths of $0-100 \mathrm{~nm}$. The goodness of the fit $R^{2}>0.8$ was set to be an acceptance threshold for the fitting quality 
within the indentation range $0-100 \mathrm{~nm}$ by fitting the Hertz-Sneddon model (Fig. 1d):

$F=\frac{E}{1-v^{2}} \frac{2 \tan \alpha}{\pi} \delta^{2}$

where $F$ is the force, $\delta$ is indentation, $\alpha$ is the tip opening angle and $v$ is the Poisson ratio. The Poisson ratio of 0.3 (adequate for polymers) was chosen. The indentation up to $100 \mathrm{~nm}$ was less than $10 \%$ of the sample height (about $1 \mu \mathrm{m}$ ) estimated from several scans, as example presented in Fig. 1c. The indentation depth applied was much lower than the height of the tips $(2.5-8 \mu \mathrm{m})$ as provided by the manufacturer. The contact point between the AFM tip and sample surface was estimated manually in each force curve as the point when the force started to deviate from a base line. Fitting of the model to experimental curves was performed using a proprietary code developed in Matlab (MathWorks, Natick, MA, USA). The fitting quality was verified using a Matlab' $R$-square $\left(R^{2}\right)$ statistic measure that is the square of the correlation between the experimental values and the predicted by model values. It has been decided arbitrarily after analysis of all curves (640 curves for each stage) that if the goodness of the fit $R^{2}$ was lower than 0.8 a force curve could not be fitted by the Hertz-Sneddon model and was removed from further analysis. The mean value of the Young's modulus and standard error were calculated from the remaining 400-600 curves for each stage.

\section{Statistical analysis}

A significant difference between means was verified using a one-way ANOVA statistical test, followed by post hoc Tukey's honestly significant difference test (Statistica 10, StatSoft, Inc., Tulsa, USA). The obtained Young's modulus values were presented as mean values with a standard error.

\section{Results}

\section{Firmness}

Changes in firmness of pears during pre-harvest maturation and postharvest storage are presented in Fig. 2a. In the preharvest period, firmness was linearly decreasing with the rate of about $1 \mathrm{~N}$ per day. For 'Xenia' pear, its value dropped from $124 \pm 12 \mathrm{~N}$ ( -34 days) to $87 \pm 5 \mathrm{~N}$ at harvest time. For 'Conference' pear, a similar decrease was observed, i.e., from $106 \pm 11 \mathrm{~N}$ ( -27 days) to $76 \pm 6 \mathrm{~N}$ at harvest time. Such a trend is qualitatively in agreement with the previous studies carried out by Murayama et al. (1998) on pears. In cold storage at $2{ }^{\circ} \mathrm{C}$ in an ambient atmosphere, fruit continued to linearly decrease its firmness although with lower rate which was about $0.3-0.4 \mathrm{~N}$ per day. In the final stage of the experiment, 'Xenia' pear softened to $46 \pm 13 \mathrm{~N}$ while 'Conference' pear to $20 \pm 3 \mathrm{~N}$. The postharvest softening is typically observed for climacteric fruit (Murayama et al. 1998, 2002), however, the rate depends on the storage method (Gwanpua et al. 2014). Cold storage in a natural atmosphere causes more rapid decrease of firmness, compared to other methods (not studied here) due to relatively high oxygen levels which helps to accelerate ripening by increasing the rate of oxidative breakdown reactions. Few days of shelf life at $20{ }^{\circ} \mathrm{C}$, that followed the cold storage stages, caused accelerated deterioration of pear firmness (squares in Fig. 2a). In the case of 'Conference' pear, shelf life caused the decrease of firmness down to $\sim 10 \mathrm{~N}$ in all shelf life points whereas for 'Xenia' pear, most of the shelf life cases significantly decreased firmness to about $16-50 \mathrm{~N}$ with much larger variability as compared to the second cultivar. It should be underlined that for one event just 7 days after the harvest, the decrease was not significant in the relation to the predated point.

\section{The Young's modulus of pear cell walls}

Figure 3a presents an example of the cell wall image (socalled "error image") depicting regions of fibrils embedded in amorphous matrix whereas Fig. $3 b$ shows the corresponding map of stiffness. In our experiments, the cantilevers with sharp tips were used which ends up in a comparable diameter with the fibrils one. In such a way, a spatial variability in sample stiffness can be probed since such a sharp tip indents either a single fibril or space between neighbouring fibrils. Figure $3 \mathrm{a}$ shows the region (the bottom part of the image area) where fibrils are apparently covered by a matrix of pectins. Its presence leads to smaller local Young's modulus depicted on the stiffness map (Fig. 3b). Figure 3c presents histograms of the Young's modulus for distant experimental stages for ten CWM fragments considered to characterize the stages. Despite large standard deviations, a clear shift of histograms for the harvest stage is visible compared to the before and after harvest ones. Therefore, to follow the time changes of the Young's modulus of cell walls, the mean value was used and a significance of the effect was checked by ANOVA post hoc analysis (at $P<0.05$ ).

The relations of the Young's modulus as a function of time, determined for the pear cell wall, are shown in Fig. 2b. The profile of changes was very similar for both cultivars but surprisingly it was different from the firmness changes presented in Fig. 2a. In the pre-harvest period, the Young's modulus of the cell wall linearly decreased from $3.2 \pm 1.8$ to $2.0 \pm 1.5 \mathrm{MPa}$ and from $1.9 \pm 1.2$ to $0.6 \pm 0.5 \mathrm{MPa}$ for 'Xenia' and for 'Conference', 
(a)
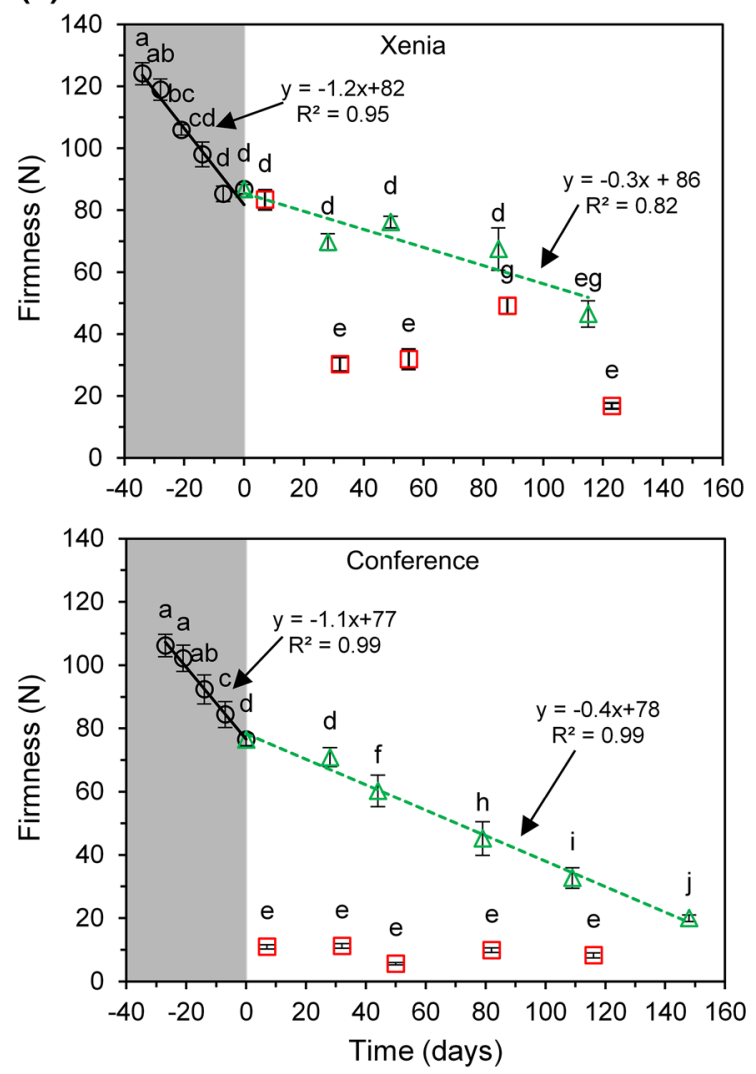

- pre-harvest

$--\Delta-$ postharve

Fig. 2 Firmness (a) and cell wall Young's modulus (b) changes for fruit collected during pre-harvest maturation (shadowed region, open circles) and during postharvest storage in a cold room at $2{ }^{\circ} \mathrm{C}$ and $\mathrm{RH}$ $\sim 80-90 \%$ in ambient atmosphere (green triangles). Time zero

respectively. The rate of decrease was about $30 \mathrm{kPa}$ per day for 'Xenia' and $45 \mathrm{kPa}$ per day for 'Conference'. The lowest stiffness of the cell wall was noted just after the harvest and it was $1.1 \pm 0.7$ and $0.2 \pm 0.1 \mathrm{MPa}$ for 'Xenia' and 'Conference', correspondingly. For samples stored longer than 40 days in cold storage in an ambient atmosphere, the cell wall Young's modulus started to increase significantly. At the end of the cold storage, i.e., after around 120 days, the change of Young's modulus seemed to be inhibited, ending at the modulus values of about 2.5 and $2.8 \mathrm{MPa}$ for 'Xenia' and for 'Conference', respectively. The variations in the modulus values during postharvest cold storage for both cultivars had similar characters that could be described by a third-order polynomial. However, the amplitude of changes was different-it was much larger for the 'Conference' pear.

The effect of shelf life on cell wall stiffness showed cultivar-dependent behaviour. For 'Conference', shelf life caused in most cases an increase of the cell wall Young's modulus compared to predated cold storage while for 'Xenia' the effect was opposite, i.e., shelf life caused the (b)
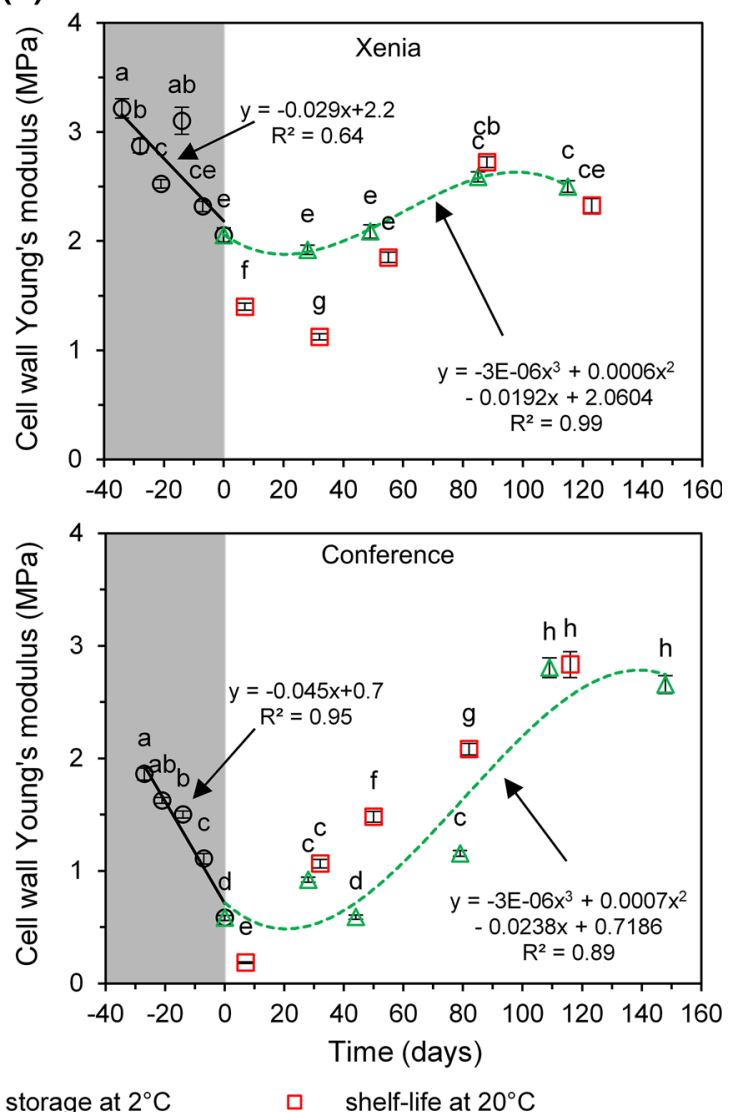

means the harvest time. Squares present shelf life points after predated storage in a cold room. Error bars are standard errors. The same letters mean no significant difference $(P<0.05)$

decrease of cell wall stiffness. From Fig. 2b, it is worth to underline that in the pre-harvest period and also during about first 3 months of postharvest period, the cell walls in 'Xenia' were stiffer than in 'Conference' pears.

\section{Discussion}

In our studies, the Young's modulus of cell walls collected from pears, determined from the AFM measurements, is generally lower as compared to previously reported values for other plants, like tomato, apple or potato. For tomato suspension cells, the Young's modulus of cell walls estimated by microcompression technique was in the range of 0.1-2.3 GPa (Blewett et al. 2000). The maximum value (of $2.3 \mathrm{GPa}$ ) was then used for a computational model of compression of single tomato suspension cells from a root radicle callus (Dintwa et al. 2011). Another study has reported the elastic modulus of the cell walls collected from pericarp of commercially grown tomatoes, also estimated using micro-compression technique, was within the 
(a)

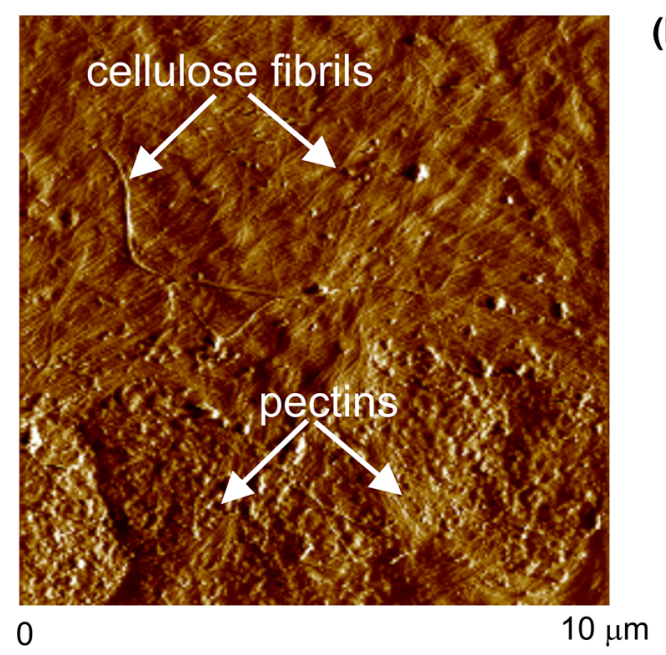

(c)
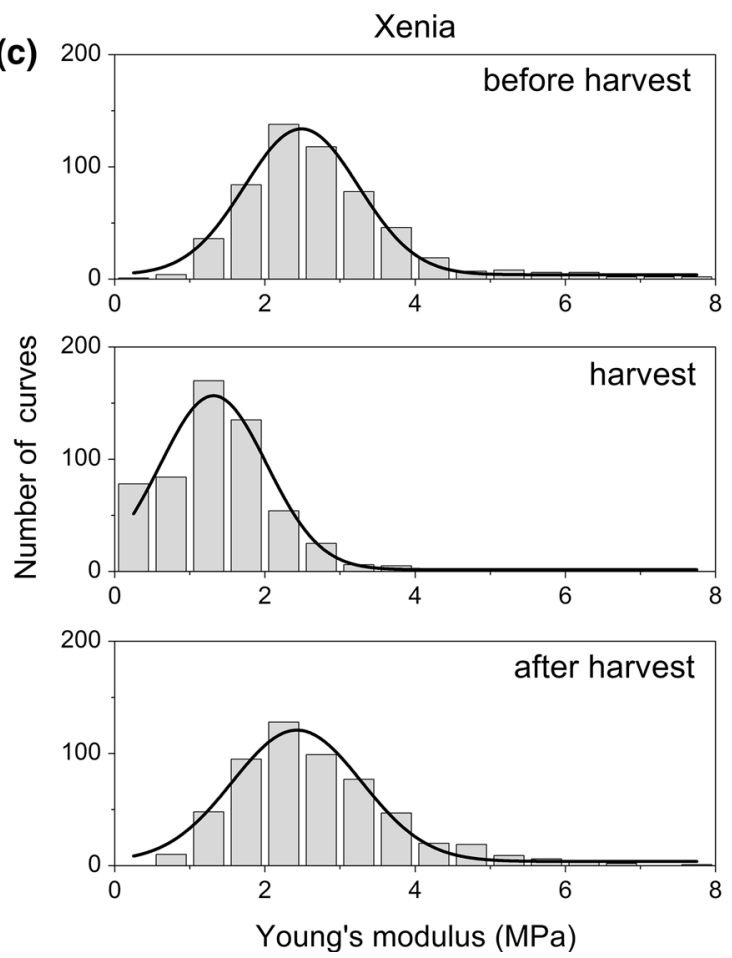

Fig. 3 The Young's modulus spatial variability in cell walls obtained for pear. a Typical AFM image of cell wall material (CWM) from a pear (error mode). Two regions are observed. In the upper part of the image cellulose fibrils are clearly visible, while in the bottom part of the image the fibrils are probably covered by the pectins' matrix. b The Young's modulus map imposed on the surface image. The

range of 30-80 MPa (Wang et al. 2006). For apples, for the purpose of a cell deformation model, the Young's modulus of cell walls of 26.4 and $52.8 \mathrm{MPa}$ was taken. For potatoes, the estimated Young's modulus of cell walls from micropenetration measurements was of $105 \mathrm{MPa}$ (Davis et al. 1998). Apart from the different commodities compared above, the main difference stems from the applied methodology of the measurements of cell wall stiffness. In (b)
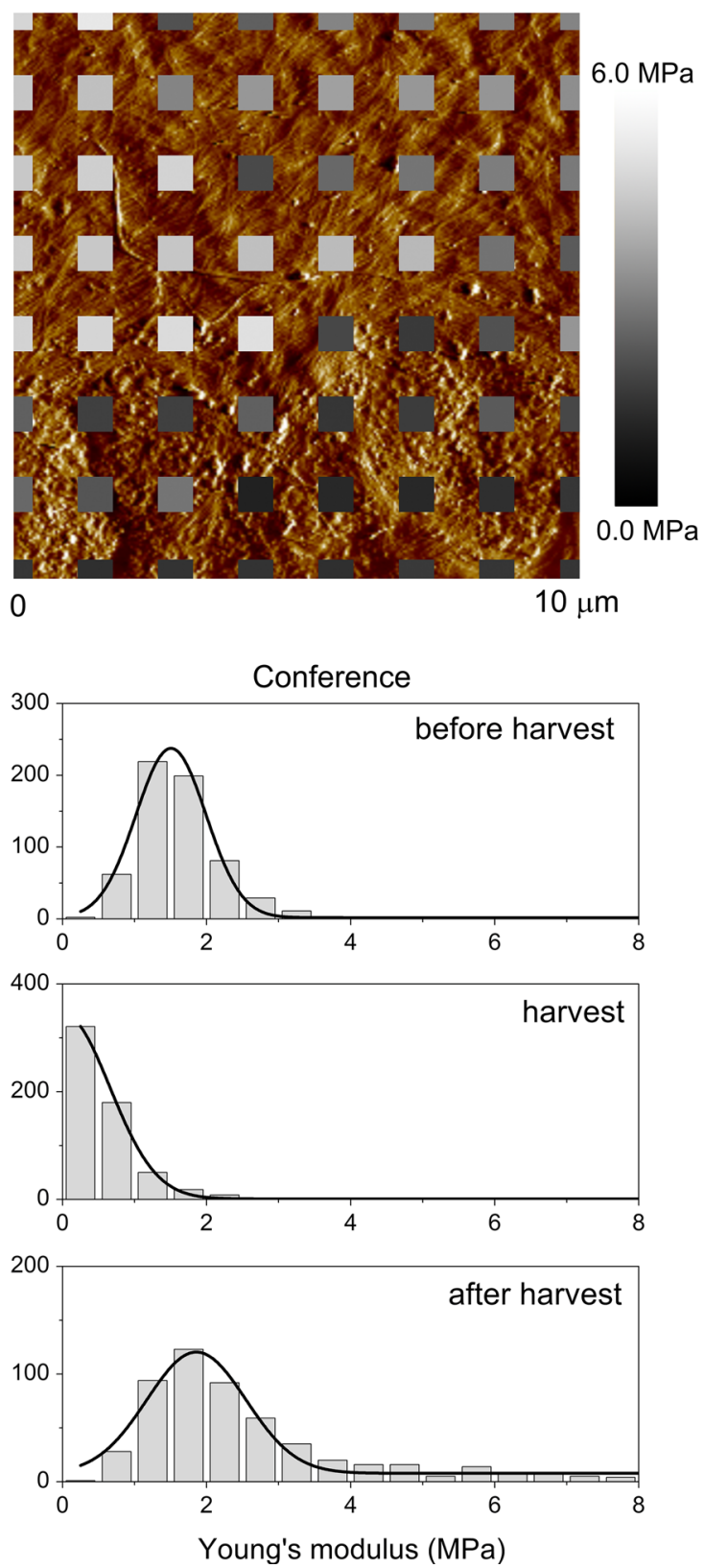

distance between centers of the grey squares is $1.4 \mu \mathrm{m}$. The various grey colors denote spatial variability of the estimated Young's modulus. c The exemplary distributions of the Young's modulus obtained for three distinct experimental stages: before harvest (20 days before harvest), at harvest and after harvest (about 80 days after harvest)

most techniques reported above, measurements are carried out on a much larger area as compared to the AFM measurements. Therefore, the obtained Young's modulus originates from a large volume of the sample. In the AFM, the average value is a sum of all measurements carried out in nanoscale. Moreover, in the previous methods the intact cells were studied and their deformations were close or over a strength of the cell wall that probably led to its 
higher stiffness compared to results obtained by low AFM indentation. It should be noted also that in the previous methods some uncertainty of estimation may have come from the assumptions about turgor or cell wall thickness which is avoided in the AFM measurements.

Similar values to the cell walls stiffness of pears observed in our studies were obtained by the AFM indentation of suspension-cultured cells of Arabidopsis thaliana (Radotic et al. 2012). For the indentation $80 \mathrm{~nm}$ stiffness of cell walls was estimated to be in the range of 0.1-1.0 MPa, depending on the age of the growing Arabidopsis cells.

\section{Why does the cell wall stiffness not correlate with fruit firmness?}

The correlation matrix built from data of all experimental stages is shown in Table 1. The correlation analysis confirmed, as observed in Fig. 2a and b, a lack of straightforward correlation between firmness and the Young's modulus of cell walls. For the entire studied period, the positive and significant $(P<0.05)$ correlation was found for 'Xenia' pear while for 'Conference' one the correlation was slightly negative and not significant (Table 1). An unambiguous and strong positive relationship between firmness and the Young's modulus for both cultivars could be found only in the pre-harvest period (Fig. 2a and b). In the postharvest period, the relation between these variables is opposite; while firmness was continuously diminishing, cell wall stiffness was increasing. Moreover, the decrease of firmness in shelf life conditions does not clearly reflect in the cell wall elasticity.

The first reason for the lack of straightforward relation of cell wall stiffness with firmness obviously comes from distinct scales of these parameters and multiple factors contributing to tissue softening. Firmness is the macroscopic parameter of tissue and it is related to the properties of several building blocks at different length scales, i.e., cell walls, middle lamella (Jarvis et al. 2003), cell size (Cybulska et al. 2012) and turgor (Vicente et al. 2007). A decline in firmness coincides with multiple coordinated processes, including dissolution of the middle lamella and solubilization of hemicellulose and pectin cell wall polysaccharides (Brummell and Harpster 2001), and turgor loss (Saladie et al. 2007). The decline in turgor causes wall relaxation that presumably is one of the reasons of changes in cell wall architecture, reduction in intercellular adhesion that results in increase of intercellular spaces and eases water transpiration (Niklas 1992; Saladie et al. 2007). Therefore the role of cell wall stiffness in firmness of fruit may be overshadowed by other components of the microscopic biomechanical model of fruit tissue as turgor and

Table 1 Correlation matrix among variables studied for pear cv. 'Conference' and 'Xenia'

\begin{tabular}{|c|c|c|c|c|c|c|c|}
\hline & Firmness & GalA in WSP & GalA in CSP & GalA in DASP & GalA in insoluble & PG & PME \\
\hline \multicolumn{8}{|l|}{ Conference } \\
\hline Cell wall Young's modulus & -0.23 & 0.14 & -0.04 & $-0.69 *$ & 0.36 & $0.65 *$ & -0.28 \\
\hline Firmness & 1.00 & -0.74 & 0.00 & $0.59 *$ & -0.42 & -0.28 & 0.36 \\
\hline GalA in WSP & & 1.00 & 0.29 & $-0.57 *$ & 0.27 & 0.09 & -0.48 \\
\hline GalA in CSP & & & 1.00 & 0.14 & -0.44 & -0.10 & 0.10 \\
\hline GalA in DASP & & & & 1.00 & -0.39 & $-0.44^{*}$ & 0.51 \\
\hline GalA in insoluble & & & & & 1.0 & 0.46 & $-0.54 *$ \\
\hline PG & & & & & & 1.00 & $-0.68 *$ \\
\hline PME & & & & & & & 1.00 \\
\hline \multicolumn{8}{|l|}{ Xenia } \\
\hline Cell wall Young's modulus & $0.52 *$ & -0.30 & -0.16 & 0.25 & $-0.56^{*}$ & $0.66^{*}$ & $0.68 *$ \\
\hline Firmness & 1.00 & $-0.84^{*}$ & -0.43 & $0.88^{*}$ & $-0.69 *$ & 0.46 & $0.81 *$ \\
\hline GalA in WSP & & 1.00 & $0.72 *$ & $-0.79 *$ & 0.41 & -0.35 & $-0.63 *$ \\
\hline GalA in CSP & & & 1.00 & -0.38 & -0.02 & -0.24 & -0.32 \\
\hline GalA in DASP & & & & 1.00 & -0.47 & 0.14 & $0.55^{*}$ \\
\hline GalA in insoluble & & & & & 1.00 & $-0.55^{*}$ & $-0.63 *$ \\
\hline PG & & & & & & 1.00 & $0.60 *$ \\
\hline PME & & & & & & & 1.00 \\
\hline
\end{tabular}

Table shows Pearson's correlation coefficients of linear regression between variables $(n=15)$

GalA galacturonic acid, WSP water soluble pectins, CSP chelator (CDTA) soluble pectins, DASP sodium carbonate soluble pectins, $P G$ polygalacturonase activity, $P M E$ pectin methylesterase activity

* Significant correlation $(P<0.05)$ 
intercellular adhesion. Moreover, in the puncture test used for firmness evaluation, tissue and cell walls are deformed over an elastic limit and finally disrupted. Thus, the cell wall elasticity measured in the range of low deformations by AFM may not directly relate to the nonlinear large deformation by the puncture probe.

The second possible reason may refer to a different intrinsic course of changes in mechanical properties of middle lamella and primary cell wall occurring in the postharvest period. Postharvest modification of pectins in the middle lamella unquestionably softens the fruit because of the decrease of cell-to-cell integrity (Jarvis et al. 2003; Vicente et al. al. 2007; $\mathrm{Ng}$ et al. 2013). It is widely accepted that this process results in the decreasing crispness, juiciness, and increasing mealiness sense due to the change of the destruction mode from cell wall rupturing to cell-to-cell debonding (Harker and Hallett 1992; Harker et al. 1997a, b). In our studies, the AFM tip probed most likely the primary cell walls due to the boiling process applied in the protocol of the alcohol insoluble residue preparation which alters the cell-cell adhesion (Marry et al. 2000; Renard 2005).

Based on our findings, the model of the fruit transition from firm and crispy to soft and mealy in the postharvest period is proposed. At the harvest date and shortly after harvest the primary cell walls were the softest in both studied pear cultivars. Simultaneously, the integrity of middle lamella was presumably still relatively high as the result of low PG activity and calcium crosslinking of homogalacturonan. Such a combination of mechanical properties and high turgor inside cells causes better tissue integrity and favorable conditions for cracking through the cell walls. It makes pear tissue firm, juicy and crispy. Then, during storage, the primary cell walls become stiffer while middle lamella decays. Both the stiffening of cell walls and deterioration of middle lamella promote the destruction of tissue through cell-to-cell debonding. This leads to soft and mealy properties of fruits.

As shown in ESM_1, GalA in pectin fractions changed during the experiment. The cell wall Young's modulus correlated negatively $(P<0.05)$ either with the content of GalA in DASP ('Conference') or with the GalA in the insoluble fractions ('Xenia') whereas in other pectin fractions such correlations were not significant (Table 1). Sodium carbonate extracts pectins covalently linked in cell wall thus the significant correlations suggest an important role of pectins strongly linked in cell walls for maintaining their mechanical properties. It may come from the unique self-assembly ability of DASP fraction observed in vitro on mica in previous studies (Cybulska et al. 2015; Zdunek et al. 2014). The structure of DASP on mica is formed as arranged in parallel, spaced and interlinked straight molecules. Although it is still not known how DASP molecules behave in natural conditions, such a gel-like structure, if existent in tissue as well, may loosen the cellulose/hemicellulose network and thereby decrease its stiffness. This is in line with a general concept of the role of pectins in cell wall assembly. They form hydrated gels that push microfibrils apart and ease their sideways slippage during cell growth (Cosgrove 2005). Moreover, it has been shown by Cybulska et al. (2015) that during postharvest storage of carrot, the network of DASP molecules on mica was lost. Therefore, one may conclude that the degradation of the covalently linked pectins is the reason of cell wall stiffening in the postharvest period.

PG and PME activities during studied period for two pear cultivars are shown in ESM_2. The correlation analysis (Table 1) showed a significant positive relationship of the Young's modulus with the PG activity for both cultivars whereas PME correlated with the cell wall stiffness for 'Xenia' cultivar only. It has been previously reported that PG has a slight influence on fruit softening (Brummell and Harpster 2001). This agrees with insignificant and inconsistent correlations of PG with firmness for two pear cultivars observed in our studies (Table 1). On the other hand, a pronounced role of PG activity on the softening of pears was found by Ahmed and Labavitch (1980). A negative, but small, correlation of PG activity with firmness was observed for 'Jonagold' apples (Gwanpua et al. 2014). Our results show that larger cell wall stiffness is associated with higher enzymatic activity of PG (Table 1). PG activity correlated also negatively either with GalA content in DASP ('Xenia') or with GalA in insoluble pectins ('Conference'). This is in agreement with the correlations of GalA with the cell wall Young's modulus. It confirms the previous conclusion that $\mathrm{PG}$ mediated degradation of covalently linked pectins in the primary cell walls results in their larger stiffness.

The elucidated role of pectins in cell wall stiffness is also in line with studies on cell wall analogs containing bacterial cellulose, xyloglucan and pectins (Cybulska et al. 2010; Gu and Catchmark 2014). Such composites, studied in the tensile test, were stiffer with decreasing content of pectins.

\section{Conclusions}

Our studies revealed that the Young's modulus of the primary cell wall in pears decreases during pre-harvest maturation and increases when fruit continues softening during postharvest storage. This discrepancy during postharvest period may be due to degradation of pectins in middle lamella causes decreasing of a cell-to-cell adhesion whereas in the primary cell wall causes its stiffening. This is in line with the theory that decreasing crispness and increasing mealiness of fruit during postharvest storage 
relate to the change of the failure mode from cell wall rupturing to cell-to-cell debonding.

Based on our results and on previous work on cell wall analogs, we can conclude that pectins play a key role in changes of cell wall stiffness during pre- and postharvest periods. The stiffness of the primary cell walls largely depends on galacturonic acid content either in sodium carbonate soluble or in insoluble pectin fraction. The PG-mediated depolymerization of these pectins causes stiffening of the primary cell walls in pear fruit. This may be linked to previously found self-assembly of the sodium carbonate soluble pectins to a regular gel-like network which is degraded during maturation. This study elucidated a general role of pectin backbone made of galacturonic acid for the mechanical properties of cell walls; however deeper insight into polysaccharide structure is necessary to fully interpret the mechanism and relation of the pre- and postharvest fruit softening with the cell wall mechanical properties. Our studies have demonstrated that the AFM technique is an useful tool to evaluate stiffness of the cell wall. It opens a venue to study the role of other cell wall components considered as important for cell wall mechanics, like hemicelluloses, neutral sugars and related enzymes.

Our study showed that the Young's modulus of cell wall in pear is in the range of few megapascals and this value is suggested for further computational models to predict mechanical properties of this fruit. However, it is important to consider the actual value of the cell wall Young's modulus which depends on the maturation stage of fruit.

Author contribution statement AZ designed experiment, interpreted data and wrote the manuscript; AK performed AFM experiment; JC prepared CWM samples, did biochemistry, and discussed role of pectins in CWM mechanics; ML proposed method and discussed results on CWM stiffness evaluation; PMP prepared software for the Young's modulus evaluation. All authors read and approved the manuscript.

Acknowledgments This study was supported by the National Science Centre. Poland DEC-2011/01/B/NZ9/00787.

Open Access This article is distributed under the terms of the Creative Commons Attribution 4.0 International License (http://creative commons.org/licenses/by/4.0/), which permits unrestricted use, distribution, and reproduction in any medium, provided you give appropriate credit to the original author(s) and the source, provide a link to the Creative Commons license, and indicate if changes were made.

\section{References}

Ahmed AE, Labavitch JM (1980) Cell wall metabolism in ripening fruit. II. Changes in carbohydrate degrading enzymes in ripening 'bartlett' pears. Plant Physiol 65:1014-1016
Albersheim P, Darvill A, Roberts K, Sederoff R, Staehelin A (2011) Plant cell walls. Garland sciences. Taylor and Francis Group, New York

Blewett J, Burrows K, Thomas C (2000) A micromanipulation method to measure the mechanical properties of single tomato suspension cells. Biotechnol Lett 22:1877-1883

Blumenkrantz N, Asboe-Hansen G (1973) New method for quantitative determination of uronic acid. Anal Biochem 54:484-489

Brummell DA, Harpster MH (2001) Cell wall metabolismin fruit softening and quality and itsmanipulation in transgenic plants. Plant Mol Biol 47:311-340

Cosgrove DJ (2005) Growth of the plant cell wall. Nat Rev Mol Cell Biol 6:850-861

Cybulska J, Vanstreels E, Ho QT, Courtin CM, Van Craeyveld V, Nicolaï B, Zdunek A, Konstankiewicz K (2010) Mechanical characteristics of artificial cell walls. J Food Eng 96:287-294

Cybulska J, Zdunek A, Konstankiewicz K (2011) Calcium effect on mechanical properties of model cell walls and apple tissue. J Food Eng 102:217-223

Cybulska J, Pieczywek PM, Zdunek A (2012) The effect of $\mathrm{Ca}^{2+}$ and cellular structure on apple firmness and acoustic emission. Eur Food Res Technol 235:119-128

Cybulska J, Zdunek A, Psonka-Antonczyk KM, Stokke BT (2013) The relation of apple texture with cell wall nanostructure studied using an atomic force microscope. Carbohydr Polym 92:128-137

Cybulska J, Zdunek A, Kozioł A (2015) The self-assembled network and physiological degradation of pectins in carrot cell walls. Food Hydrocoll 43:41-50

Davies GC, Hiller S, Bruce DM (1998) A membrane model for elastic deflection of individual plant cell walls. J Texture Stud 29:645-667

Dintwa E, Jancsók P, Mebatsion HK, Verlinden B, Verboven P, Wang CX, Thomas CR, Tijskens E, Ramon H, Nicolaï B (2011) A finite element model for mechanical deformation of single tomato suspension cells. J Food Eng 103:265-272

Dubois MK, Gilles A, Hamilton JK, Rebers PA, Smith F (1956) Colorimetric method for determination of sugars and related substances. Anal Chem 28:350-356

Fanta SW, Abera MK, Aregawi WA, Ho QT, Verboven P, Carmeliet J, Nicolai BM (2014) Microscale modeling of coupled water transport and mechanical deformation of fruit tissue during dehydration. J Food Eng 124:86-96

Fernandes AN, Chen X, Scotchford CA, Walker J, Wells DM, Roberts CJ, Everitt NM (2012) Mechanical properties of epidermal cells of whole living roots of Arabidopsis thaliana: an atomic force microscopy study. Phys Rev E 85:021916

Gu J, Catchmark JM (2014) Roles of xyloglucan and pectin on the mechanical properties of bacterial cellulose composite films. Cellulose 21:275-289

Gwanpua SG, Van Buggenhout S, Verlinden BE, Christiaens S, Shpigelman A, Vicent V, Kermani ZJ, Nicolai BM, Hendrickx MC, Geeraerd A (2014) Pectin modifications and the role of pectin-degrading enzymes during postharvest softening of Jonagold apples. Food Chem 158:283-291

Harker FR, Hallett IC (1992) Physiological changes associated with development of mealiness of apple fruit during cool storage. HortsScience 27:1291-1294

Harker FR, Redgwell RJ, Hallett IC, Murray SH (1997a) Texture of fresh fruit. In: Janick J (ed) Horticultural reviews, vol 20. Wiley, New York, pp 122-202

Harker FR, Stec MGH, Hallett IC, Bennett CL (1997b) Texture of parenchymatous plant tissue: a comparison between tensile and other instrumental and sensory measurements of tissue strength and juiciness. Postharvest Biol Technol 11:63-72

Hayot CM, Forouzesh E, Goel A, Avramova Z, Turner JA (2012) Viscoelastic properties of cell walls of single living plant cells 
determined by dynamic nanoindentation. J Exp Bot 63:2525-2540

Hiller S, Bruce DM, Jeronimidis G (1996) A micro-penetration technique for mechanical testing of plant cell walls. J Texture Stud 27:559-587

Jarvis MC (2011) Plant cell walls: supramolecular assemblies. Food Hydrocoll 25:257-262

Jarvis MC, Briggs SPH, Knox JP (2003) Intercellular adhesion and cell separation in plants. Plant, Cell Environ 26:977-989

Kurland NE, Drira Z, Yadavall NK (2012) Measurement of nanomechanical properties of biomolecules using atomic force microscopy. Micron 43:116-128

Kuznetsova TG, Starodubtseva MN, Yegorenkov NI, Chizhik SA, Zhdanov RI (2007) Atomic force microscopy probing of cell elasticity. Micron 38:824-833

Lekka M (2012) Atomic force microscopy: a tip for diagnosing cancer. Nat Nanotechnol 7:691-692

Lekka M, Laidler P (2009) Applicability of AFM in cancer detection. Nat Nanotechnol 4:72-73

Lekka M, Pogoda K, Gostek J, Klymenko O, Prauzner-Bechcicki S, Wiltowska-Zuber J, Jaczewska J, Lekki J, Stachura Z (2012) Cancer cell recognition-mechanical phenotype. Micron 43:1259-1266

Lesniewska E, Adrian M, Klinguer A, Pugin A (2004) Cell wall modification in grapevine cells in response to UV stress investigated by atomic force microscopy. Ultramicroscopy 100:171-178

Loparic M, Wirz D, Daniels AU, Raiteri R, VanLandingham MR, Guex G, Martin I, Aebi U, Stolz M (2010) Micro- and nanomechanical analysis of articular cartilage by indentationtype atomic force microscopy: validation with a gel-microfiber composite. Biophys J 98:2731-2740

Marry M, McCann MC, Kolpak F, White AR, Stacey NJ, Roberts K (2000) Extraction of pectic polysaccharides from sugar-beet cell walls. J Sci Food Agr 80:17-28

Mashmoushy H, Zhang Z, Thomas CR (1998) Micromanipulation measurement of the mechanical properties of baker's yeast cells. Biotechnol Tech 12:925-929

Milani P, Gholamirad M, Traas J, Arneódo A, Boudaoud A, Argoul F, Hamant O (2011) In vivo analysis of local wall stiffness at the shoot apical meristem in Arabidopsis using atomic force microscopy. Plant J 67:1116-1123

Murayama H, Takahashi T, Honda R, Fukushima T (1998) Cell wall changes in pear fruit softening on and off the tree. Postharvest Biol Tech 14:143-149

Murayama H, Katsumata T, Horiuchi O, Fukushima T (2002) Relationship between fruit softening and cell wall polysaccharides in pears after different storage periods. Postharvest Biol Tech 26:15-21

Ng JKT, Schröder R, Sutherland PW, Hallett IC, Hall MI, Prakash R, Smith BG, Melton LD, Johnston JW (2013) Cell wall structures leading to cultivar differences in softening rates develop early during apple (Malus $\times$ domestica) fruit growth. BMC Plant Biol $13: 183$

Niklas KJ (1992) Plant biomechanics. An engineering approach to plant form and function. The University of Chicago Press, Chicago, London

Peaucelle A, Braybrook SA, le Guillou L, Bron E, Kuhlemeier C, Ho $\mathrm{H}$ (2011) Pectin-induced changes in cell wall mechanics underlie organ initiation in Arabidopsis. Curr Biol 21:1720-1726
Pieczywek MP, Zdunek A (2014) Finite element modelling of the mechanical behaviour of onion epidermis with incorporation of nonlinear properties of cell walls and real tissue geometry. J Food Eng 123:50-59

Radmacher M, Cleveland JP, Fritz M, Hansma HG, Hansma PK (1994) Mapping interaction forces with the atomic force microscope. Biophys J 66:2159-2165

Radmacher M, Fritz M, Hansma PK (1995) Imaging soft samples with the atomic force microscope: gelatin in water and propanol. Biophys J 69:264-270

Radotić K, Roduit C, Simonović J, Hornitschek P, Fankhauser C, Mutavdzić D, Steinbach G, Dietler G, Kasas S (2012) Atomic force microscopy stiffness tomography on living Arabidopsis thaliana cells reveals the mechanical properties of surface and deep cell-wall layers during growth. Biophys J 103:386-394

Redgwell RJ, Melton LD, Brasch DJ (1988) Cell-wall polysaccharides of kiwifruit (Actinidia deliciosa): chemical features in different tissue zones of the fruit at harvest. Carbohydr Res 182:241-258

Renard CMGC (2005) Variability in cell wall preparations: quantification and comparison of common methods. Carbohydr Polym 60:515-522

Routier-Kierzkowska AL, Smith RS (2013) Measuring the mechanics of morphogenesis. Curr Opin Plant Biol 16:25-32

Routier-Kierzkowska AL, Weber A, Kochova P, Felekis D, Nelson BJ, Kuhlemeier C, Smith RS (2012) Cellular force microscopy for in vivo measurements of plant tissue mechanics. Plant Physiol 158:1514-1522

Saladie M, Matas AJ, Isaacson T, Jenks MA, Goodwin SM, Niklas KJ, Xiaolin R, Labavitch JM, Shackel KA, Fernie AR, Lytovchenko A, O'Neill MA, Watkins CB, Rose JK (2007) A reevaluation of the key factors that influence tomato fruit softening and integrity. Plant Physiol 144:1012-1028

Shiu C, Zhang Z, Thomas CR (1999) A novel technique for the study of bacterial cell mechanical properties. Biotechnol Tech 13:707-713

Sneddon IN (1965) The relation between load and penetration in the axisymmetric Boussinesq problem for a punch of arbitrary profile. Int J Eng Sci 3:47-57

Thomas CR, Zhang Z, Cowen C (2000) Micromanipulation measurements of biological materials. Biotechnol Lett 22:531-537

Vicente AR, Saladie' M, Rose JKC, Labavitch JM (2007) The linkage between cell wall metabolism and fruit softening: looking to the future. J Sci Food Agr 87:1435-1448

Wang CX, Pritchard J, Thomas CR (2006) Investigations of the mechanics of single tomato fruit cells. J Texture Stud 37:597-606

Wei J, Ma F, Shi S, Qi X, Zhu X, Yuan J (2010) Changes and postharvest regulation of activity and gene expression of enzymes related to cell wall degradation in ripening apple fruit. Postharvest Biol Tech 56:147-154

Zdunek A, Kurenda A (2013) Determination of the elastic properties of tomato fruit cells with an atomic force microscope. Sensors 13:12175-12191

Zdunek A, Kozioł A, Pieczywek PM, Cybulska J (2014) Evaluation of the nanostructure of pectin, hemicellulose and cellulose in the cell walls of pears of different texture and firmness. Food Bioprocess Tech 7(12):3525-3535 